\title{
The Politics of Recognition versus the Politics of Hatred
}

\author{
ARRAN GARE
}

Abstract Hatred of America expressed in the 11 September attack is more than matched by the hatred by Americans for Islamists expressed in the war on Afghanistan, the War against Terror and the threatened wars against the 'Axis of Evil'. It is argued here that there is a pattern of selfreinforcing hatred operating in the world set in motion by the actions of the United States, particularly by George Bush Snr, and embraced and used by George Bush Jr to reinforce and further develop this pattern. To oppose this it is necessary to understand how hatred is generated, how this system operates and how Bush is exploiting it, and then to provide an alternative. It is argued this requires a new story of civilisation as the quest for justice understood as true recognition to oppose to the myths based on hatred promulgated by Bush. In terms of this story, the extreme economic, social, political and military policies of Bush and the myths used to justify them should be recognised for what they are, the challenge of barbarism to civilisation.

\section{Hatred}

In February 1998, Osama bin Laden issued a manifesto for 'The International Islamic Front for Jihad against Jews and Crusaders'. It declared that 'To kill the Americans and their allies-civilians and military-is an individual duty for every Muslim who can do it in any country in which it is possible to do it... ${ }^{1}$ Bin Laden established al-Qaeda as the base for a network to provide money, training and logistic support to radical Islamist groups in Yemen, Egypt, Algeria, Russia, the Philippines and many other countries. Pre-existing al-Qaeda, this was 'an informal network of small, loosely organized underground cells with support centres scattered around the world: in the United States, the Persian Gulf countries, Germany, Switzerland, Scandinavia, Sudan, Pakistan and Afghanistan'.2 The 11 September attack on the twin towers of the World Trade Center was the work of this network (although there is no conclusive evidence that bin Laden had a major role). Ian Buruma and Avishai Margalit in 'Occidentalism', published in The New York Review of Books, characterised this as Islamism and as part of a long tradition of hostility toward Western civilisation, a tradition that includes Marxism, Stalinism, Nazism, Japanese and Italian fascism and Maoism. The targets of the enemies of the West are 'materialism, liberalism, capitalism, individualism, humanism, rationalism, socialism, decadence and moral laxity',

1. Cited by Pankaj Mishra, 'The Afghan Tragedy', The New York Review of Books, Vol. 49, No. 1, 2002, p. 46.

2. Ibid. 
and the bourgeoisie. 'Enemies of the West usually aspire to be heroes', Buruma and Margalit wrote.

Islamism, Nazism, fascism, communism are all heroic creeds. ... The common enemy of revolutionary heroes is the settled bourgeois, the city dweller, the petty clerk, the plump stockbroker, going about his business, the kind of person, in short, who might have been working in an office in the World Trade Center. It is a peculiar trait of the bourgeoisie, perhaps the most successful class in history ... to be hated so intensely. 4

After the defeat of Nazism, fascism and communism and the demise of Maoism, the West is again under challenge. The Islamists hate everything the West stands for. Islamism, like fascism and communism, has different forms. Baruma and Margalit characterise these as 'Stalinist' and 'Trotskyite':

Ayotolla Khomeini was a 'Stalinist' in the sense that he wanted to stage a revolution in one significant country, Iran, before worrying about exporting it. Bin Laden, by contrast, is a 'Trotskyite,' who views Afghanistan as a base from which to export revolution right away. There is a tension between the 'Stalinists' and the 'Trotskyites' within the Islamist movement. September 11 gave the 'Trotskyites' an advantage. ${ }^{5}$

Ronald Steel wrote on 14 September 2001 in the New York Times, 'they hate us because we champion a "new world order" of capitalism, individualism, secularism and democracy that should be the norm everywhere.' 6 The West is directly and immediately threatened by those who hate it.

This has provoked outrage in the United States. What al-Qaeda has done is unprecedented. The indigenous populations of North and South America, Australia, New Zealand and Hawaii who had not been annihilated had come to accept their total subjugation. The colonised of Africa, Asia and the Middle East who opposed the empires of Europe in the 19th and 20th centuries sometimes attacked their armies, but always in their own countries. They never attacked the cities of Europe. Al-Qaeda's actions are abominable. Bin Laden and al-Qaeda are seen as the quintessence of evil. The Arabs and to some extent the Islamic world generally are now seen as menacing force threatening the civilised world. Israel is now seen as a bastion of the West and given the green light to tear up its treaties with the Palestinians and to move to expand its lebensraum. In the United States a Sikh was murdered because he looked like an Arab.

All this has been a great boon to President George Bush Jr and his supporters. Coming to power in an economic crisis as a minority president from an election in which the Supreme Court prevented a proper count of votes, Bush soon had an

3. Ian Buruma and Avishai Margalit, 'Occidentalism', The New York Review of Books, Vol. 49, No. 1, 2002, pp. 4-7, p. 4.

4. Ibid., p. 6.

5. Ibid., p. 7.

6. Quoted by Noam Chomsky, 'Chomsky interview 5', p. 5, Znet, http://zmag.org. 
$86 \%$ approval rating. ${ }^{7}$ Nearly $80 \%$ of Americans support his policy of indefinite detention for non-citizens suspected of being a threat to national security and $70 \%$ support eavesdropping on conversations between lawyers and their clients. Through the USA Patriot bill (the act for Uniting and Strengthening America by Providing Appropriate Tools to Intercept and Obstruct Terrorism) the FBI, CIA and other government agencies have been given greater freedom to eavesdrop, snoop and secretly investigate, without court authorisation, those they choose to target. By invoking the 'War against Terror' Bush has gained a virtual free hand to mobilise the might of the US military against those who resist its power. Bypassing and thereby weakening the United Nations and without a formal declaration of war he has invaded and overthrown the government of a sovereign state. He has unilaterally abandoned the ICBM treaty with Russia and revived the quest for total military domination of the world through the control of space. He is threatening war against the 'Axis of Evil', Iraq, Iran and North Korea. Hatred now widespread among Americans for the people who might have provided backup support for, or even sympathised with the people who crashed aircraft into the World Trade Center towers, killing 3000 odd Americans (the perpetrators cowardly died in the crash) has given Bush the mandate to terrorise the rest of the world.

\section{Bin Laden and the Gulf War}

How did bin Laden come to hate the West? Bin Laden was initially recruited to support the fight by the CIA-backed Mujahideen against communism in Afghanistan. Zbigniew Brzezinksi, former National Security Advisor, recently revealed that 'on July 3,1979, unknown to the American public and Congress, President Carter had secretly authorised $\$ 500$ million to create an international terrorist movement that would spread Islamic fundamentalism in Central Asia and "destabilise" the Soviet Union'. In the following years as a continuation of this project, dubbed Operation Cyclone, the CIA 'poured $\$ 4$ billion into setting up Islamic training schools in Pakistan (Taliban means "student")' ${ }^{8}$ Future members of al-Qaeda were trained in terrorist techniques in the CIA's spy training camp in Virginia. Bin Laden was recruited as part of this project. His hostility then was directed against Russians. On his return to Saudi Arabia after the overthrow of the Soviet backed government in Afghanistan, bin Laden was increasingly disaffected by Saudi Arabia's corrupt, incompetent and brutal regime. However, it was the Gulf War and its aftermath that crystallised his radical views. When Iraq invaded Kuwait, bin Laden offered to raise an army of Arab volunteers to defend Saudi Arabia. To his shock he was ignored by the Saudi royal family who invited half a million US troops into Saudi Arabia. Bin Laden was outraged by the proximity of US soldiers, including women in unIslamic dress, to the holiest sites of Islam. He was even more outraged when thousands stayed after the war, despite the wishes of the Saudi government. After

7. Walden Bello, 'The American Way of War', 30 December 2001, p. 5, Znet, http:// www.zmag.org.

8. John Pilger, 'The Colder War', The Mirror, 29 January 2002, Znet, http://www.zmag.org. 
the war had destroyed much of Iraq, the US stopped short of removing Saddam Hussein (whose rise to power had been supported by the CIA). The USA encouraged uprisings by Shia Muslim and Kurd dissidents, and then withdrew its support, leaving them to be slaughtered. The USA then led a blockade of the country, starving its population, depriving it of medicine and other essential health products for preventing disease, killing hundreds of thousands of Iraqi children. The US government's attitude to these children was expressed in 1996 in a widely publicised answer to a question put to the US Secretary of State, Madeline Albright. Leslie Stahl of CBS, speaking of US sanctions against Iraq, put the question: 'We have heard that half a million children have died. I mean, that's more children than died in Hiroshima. And-and you know, is the price worth it?' Albright replied, 'I think this is a very hard choice, but the price-we think the price is worth it'. ${ }^{9}$ Bin Laden expressed outrage at this embargo on Iraq and its consequences. That is, bin Laden's attitudes to USA were largely a product of the war against Iraq and its aftermath.

The war against Iraq was prosecuted by President George Bush Snr, George Bush Jr's father. Overtly it was a defence of the right of nations to autonomy within the New World Order. However, there were some very unusual aspects to this war apart from the final failure to remove Hussein from power. Eight days before the attack on Kuwait, with tens of thousands of Iraqi troops massed on the border, Hussein summoned the US Ambassador, April Glaspie, and launched into a tirade about the role of Iraq in checking the influence of Iran and the ingratitude of those who benefited from this, against the role of the British in the region (who had carved out Kuwait from Iraq), against the economic aggression of Kuwait and the United Arab Emirates in agitating for lower oil prices, and against Kuwaiti incursions into the neutral zone between Kuwait and Iraq. Glaspie sympathised with Saddam about colonialists and pointed out that many Americans wanted the price of oil to remain high. She went on:

I think I understand this. I have lived here for years. I admire your extraordinary efforts to rebuild your country. I know you need funds. We understand that and our opinion is that you should have the opportunity to rebuild your country. But we have no opinion on the Arab-Arab conflicts, like your border disagreement with Kuwait. I was in the American Embassy in Kuwait during the later 1960s. The instructions we had during this period were that we should express no opinion on this issue and that the issue is not associated with America. James Baker has directed our official spokesmen to emphasize this instruction. We hope you can solve this problem using any suitable methods. ${ }^{10}$

9. Quoted by Cafearabica: The Arab-American Online Community Center, http://www.cafearabica.com, p. 1.

10. 'Excerpts from Iraqi Document on Meeting with U.S. Envoy', The New York Times International, 23 September 1990, 19, http://chss.montclair.edu/english/furr/glaspie.html, p. 5. 
Hussein went on, 'if we are unable to find a solution, then it will be natural that Iraq will not accept death, even though wisdom is above everything else'. ${ }^{11}$ Glaspie informed him that she would fly to USA immediately hoping to meet with President Bush. In response, Bush sent a very weak memo to Hussein, not mentioning the troop build up, Kuwait sovereignty or any interest in defending Kuwait. It appeared to be a green light to Hussein to invade Kuwait. ${ }^{12}$

After the invasion by Iraq, Bush not only sought to defend Kuwait. He extended his goal to invading Iraq. After the anti-Iraq build up of forces the US negotiators went out of their way to avoid a diplomatic solution. They wanted a war. Like a scene from George Orwell's Nineteen Eighty Four, Iraq was portrayed as a major military power which could possibly defeat the invading forces, or at least inflict huge casualties. This was followed by the invasion, 'Desert Storm', in which, to the great relief of people in America (and Britain) watching their television screens, the Iraqi troops were routed. It is difficult to know whether Iraq was set up for this whole scenario or whether Bush the Elder, initially indifferent to the fate of Kuwait, seized the opportunity for a war in which he and his supporters could be portrayed as conquering heroes. The outcome was the same. Desert Storm became an icon of US military supremacy, the US increased its power over the Middle East and its oil, and millions of Iraqis who in no way were responsible for the invasion of Kuwait were, and are still being, killed, maimed, starved or impoverished.

While in USA the Gulf War became a symbol of success, in the Arab world it highlighted the indifference of the West to the lives and religious beliefs of Arabs and other Islamic peoples. The war symbolised the history of US behaviour in the region where, since the Second World War, the Palestinians have lost their homeland and Israel's expansion has been supported, the USA has engineered the overthrow of regimes committed to the welfare of their populations and supported corrupt and oppressive regimes, and conflicts between different countries in the region have been fostered. Before the invasion of Kuwait, USA appeared to support Iraq's attack on Iran, but then supplied weapons to both sides. The Gulf War also made manifest and became a symbol of the pro-American orientation of its corrupt rulers. It was this state of affairs that inevitably provoked Arabs such as bin Laden and those who joined al-Qaeda.

The tactics of al-Qaeda have been dictated by their situation. The overwhelming military superiority of the US with their capacity to kill hundreds of thousands and, if the situation arises, hundreds of millions of people with missiles and by bombing them from the air with little risk to their own military personnel makes it impregnable to conventional warfare. To such people terrorism is the only alternative to passive submission. As Chalmers Johnson, in his book Blowback: The Costs and Consequences of American Empire (published in April, 2000, before the September attack) wrote, 'What US officials denounce as unprovoked

11. Ibid., p. 7.

12. See Justin Rumondo, 'The Gulf War in Retrospect: the "Isolationists" Were Right', Behind the Headlines, 15 January 2001, p. 3, http://www.antiwar.com/justin/j011501.html. See also, Elaine Sciolino, The Outlaw State: Saddam Hussein's Quest for Power and the War in the Gulf (New York: John Wiley, 1991). 
terrorist attacks on its innocent citizens are often meant as retaliation for previous American imperial actions. Terrorists attack innocent and undefended American targets precisely because American soldiers and sailors firing cruise missiles from ships at sea or sitting in B-52 bombers at extremely high altitudes or supporting brutal and repressive regimes from Washington seem invulnerable.' 13

\section{Bush the Younger and the war against Afghanistan}

Bush the Younger reaped what his father had sown. Having gained power but not legitimacy or even minimal respect, Bush presided over a divided nation. He was viewed as a slightly moronic fraternity boy and derided on prime-time television. The attacks of 11 September 2001 changed all this. After disappearing for several hours Bush emerged (when it was clear there was no longer any danger) to condemn the cowardly actions of the terrorists. Not only did the horror of this action and hostility to its perpetrators unite the nation, but it provided Bush with an opportunity to wage another war, this time in a country even weaker than Iraq. Now he was America's Commander in Chief. The main suspect for the attack, apart from the perpetrators who were dead, was bin Laden who was residing in Afghanistan. The Taliban government offered to try bin Laden, or even hand him over to a neutral country for trial if the US government would supply some evidence against him. If the US government had, as it claimed, irrefutable evidence for bin Laden's culpability, then this was the best chance it had of bringing him to justice, but this offer was rejected. Afghanistan was attacked and bin Laden, as most knowledgeable political commentators predicted he would, vanished. So why did Bush refuse to accept the Afghanistan government's offer? Why, instead, did the US invade Afghanistan? It is very unlikely that the Taliban government of Afghanistan had anything to do with the 11 September events, even if bin Laden and al-Qaeda had.

It seems to have escaped most people that the government of Afghanistan was not bin Laden or al-Qaeda. ${ }^{14}$ Bin Laden has disappeared and most al-Qaeda appear to have left the country. However, some justification was offered for this course of action. The Taliban were vilified as a fundamentalist Islamic regime hostile to Western values. They were intolerant and undemocratic. They were making Westernised women in Kabul wear the traditional burka and excluding them from education, assaulting them when they showed their faces in public. This particularly incensed Bush's wife, Laura, and America's main supporter, the British bulldog Tony Blair. The Taliban were also punishing thieves by cutting off their hands and were displaying for four days the bodies of those they executed for more serious crimes such as adultery, rape and murder.

Was it the quest to liberate women and to replace its legal system that motivated the US war against Afghanistan? The USA supplied most of the money and weapons to the Mujahideen to overthrow the earlier Westernising regime that

13. Cited from his own work in Chalmers Johnson, 'Hubris Invites a Backlash', The Australian, 26 December 2001, p. 9.

14. This was pointed out by Jonathan Steele, 'Fighting the Wrong War', The Guardian, 11 December 2001, http://www.zmag.org. 
had attempted to liberate women from traditional roles. Under that regime, female illiteracy declined from $98 \%$ to $75 \%$ and women were granted equal rights with men in civil law and the Constitution. ${ }^{15}$ The leading proponents of Westernisation were killed by the Mujahideen. Women immediately lost their rights and the leaders of a number of the warring factions condoned their rape by armed guards. The US government supported these more extremist, more brutal and more antifeminist Mujahideen groups over the moderates. The murder and rape of women - and boys, in Kandahar outraged Mullah Mohammed Omar, the leader of the Taliban and was one of the major motivations for his drive for power. ${ }^{16}$ The Taliban emerged and gained power largely because they put an end to widespread violence, rape and enforced prostitution, and ended corruption. The constraints imposed on women in Kabul were part of the effort to regain order. The Taliban were in fact implementing a rough village justice in a country devastated and reduced to anarchy by the proxy war fought by USA against the Soviet Union. Replacing them with the Northern Alliance of the warlords who the Taliban had displaced can only return Afghanistan to the earlier brutal chaos, as indeed appears to be occurring, ${ }^{17}$ and the Islamic system of justice has been retained. There is little prospect for improving the lot of women. How could one possibly justify the huge casualties and turmoil of a new war for such an outcome?

There is a more obvious reason for the war against Afghanistan. The web site for the Italian-based 173rd Airborne Brigade, under the banner 'Future map of the Middle East' and 'Kick their ass and take their gas', had a map which renamed Afghanistan 'Texaco', Iraq 'Chevron', Pakistan 'Exxon' and Iran 'New Texas'. Afghanistan was referred to on another map as 'Lake America'. ${ }^{18}$ If such thinking was pervasive among the troops, it is also likely to have been central to the thinking of their leaders. Control of Afghanistan will serve US control of the immense reserves of oil and gas in the countries that have emerged as independent nations from the former Soviet Union, providing an alternative route (other than through Iran) to export this oil and gas. Corrupt warlords might not do much for the Afghans, but they will be far more likely to serve US interests than the Taliban.

However, if the goal were merely to remove the Taliban to gain control over the region, there were easier ways to proceed. At a meeting in Peshawar, Afghan opponents of the Taliban, including 'tribal leaders, Islamic scholars, fractious politicians and former guerrilla commanders', unanimously 'demanded an end to the bombing of Afghanistan', urging other means to overthrow the Taliban be adopted. ${ }^{19}$ Abdul Huq, considered as "perhaps the most important leader of

15. See Rasil Basu, 'The Rape of Afghanistan', 30 December 2001, p. 1. Znet, http:// www.zmag.org/basurape.htm, p. 1.

16. See Robert Fisk, 'War on Terrorism: Rise and Fall of a Village Cleric who Fought "Criminals and Traitors" ', 7 December 2001, Znet, http://www.zmag.org, p. 2.

17. See Mark MacKinnon, 'Warlords Imperil Afghan Peace', The Globe and Mail, 22 January 2002, http://www.zmag.org.

18. Reuters, 'US Paratroopers' Web Site Taken Out of Action', Znet, 27 September 2001. http:// www.zmag.org.

19. Noam Chomsky, 'The War in Afghanistan', Excerpted from Lakdawla lecture, New Delhi, p. 6f. Znet, http://www.zmag.org. 
anti-Taliban opposition among Afghans or Pashtun nationality based in Pakistan' advised the avoidance of bloodshed wherever possible. 'The US', Haq said,

is trying to show its muscle, score a victory and scare everyone in the world. They don't care about the suffering of the Afghans or how many people we will lose. And we don't like that. Because Afghans are now being made to suffer for these Arab fanatics, but we all know who brought these Arabs to Afghanistan in the 1980s, armed them and gave them a base. It was the Americans and the CIA. And the Americans who did this all got medals and good careers, while all these years Afghans suffered from these Arabs and their allies. Now, when America is attacked, instead of punishing the Americans who did this, it punishes the Afghans. ${ }^{20}$

'Instead of bombing', Huq argued, 'we should undermine the central leadership, which is a very small and closed group and which is also the only thing which holds them all together. If they are destroyed, every Taliban fighter will pick up his gun and his blanket and disappear back home, and that will be the end of the Taliban.' ${ }^{21}$ The final collapse of the Taliban would suggest that Huq was right, but the US refused to support him. He entered Afghanistan anyway to create a revolt within the Taliban, establishing contacts with second level Taliban commanders and ex-Mujahideen, but his efforts were undermined by US bombing and he was captured and killed. The US appears to have had another agenda.

\section{The new myth of American nationhood}

The more important agenda was to enable Bush to portray himself as a hero to augment his power to implement his extreme right-wing military, economic, political and social policies while retaining his standing and power. How could he do this? George Monbiot has noted that 'the more powerful a nation becomes, the more it asserts its victimhood'. ${ }^{22}$ The British, for instance, regarded the atrocities perpetrated against its compatriots in the Black Hole of Calcutta or during the Indian mutiny and the siege of Khartoum to be the worst atrocities of the 18th and 19th centuries. These events "came to symbolise the barbarism and ingratitude of the savage races the British had sought to rescue from their darkness' ${ }^{23}$ They also distracted people from the shortcomings of British society. Now, the attack on New York is portrayed as the worst thing to have happened to any nation in recent times. They have forgotten the innocent civilians killed by US bombing or by US supported terrorists, including the civilians killed in the firebombing of Dresden $(135,000)$ and Tokyo $(85,000$ in one night), the atomic bombing of Hiroshima and Nagasaki, three million civilians killed by the US in the Korean

20. Ibid., p. 7 .

21. Ibid.

22. George Monbiot, 'Both Saviour and Victim', The Guardian, 29 January 2002, p. 1 http:// www.zmag.org.

23. Ibid. 
war, two to three million civilians killed through bombing in Viet Nam, Cambodia and Laos during the Vietnam War, 200,000 civilians killed following the US supported invasion of East Timor - a third of its population, more than a million civilians killed so far in Iraq and vast numbers of civilians killed by US-supported dictatorships and terrorists in the Middle East and Central and South America. ${ }^{24}$

Bush is creating a new myth of nationhood, casting America 'simultaneously as the world's saviour and the world's victim: a sacrificial messiah, on a mission to deliver the world from evil'. ${ }^{25}$ Through this Bush the Younger has gained the highest approval ratings for the longest time of any president and at a time when more and more Americans are suffering from his economic policies. It has become unpatriotic to criticise him.

According to this new myth, the destiny of America is to fight a 'War against Terrorism', beginning with Afghanistan and continuing indefinitely with or without the support of others. Thomas Walkom of the Toronto Star has identified the crucial importance of this new mythology.

For Bush, an end to the war against terrorism could spell political disaster. Look what happened to his father. George Bush Snr. was an immensely popular president when he was waging war against Iraq. But as soon as the fighting stopped, his ratings tumbled. Without war to focus their attention, Americans remembered why they disliked Bush and threw him out of the White House. By contrast, Bush Jr. has discovered the perfect way to avoid his father's fate; war without end. ${ }^{26}$

The terrorists are everywhere. The Taliban were only tools. Even bin Laden is only one of its many leaders. That bin Laden has not been captured suits the new mythology since it extends the suspense. Whenever people's attention appears to have lapsed, new discoveries about al-Qaeda or bin Laden are made. A notebook found in a bombed out house proves al-Qaeda is planning a nuclear attack. A video found in Singapore demonstrated that al-Qaeda is preparing another terror bombing. Fortunately these fanatics make plenty of videos. They video each other plotting, planning attacks and having dinner parties, and then leave them lying around in bombed out houses. Reporters poring over the rubble of Kabul also found foul smelling liquids and notebooks filled with equations. These were taken by them as evidence of an al-Qaeda germ warfare programme. Fortunately, members of al-Qaeda write down many of their schemes in English. For instance, 'In November ... journalists searching through a Kabul home said to be an al-Qaeda training center found hand-printed plans, in English, on how to manufacture a multi-million-dollar, homemade stealth bomber' ${ }^{27}$ Walkom analysed the power of this plot:

24. For a brief survey of these, see Robin Miller, 'Washington's Own Love Affair With Terror', Znet, http://www.zmag.org/millerterror.htm.

25. Ibid.

26. Thomas Walkom, 'Bush Counts on War Without End', Toronto Star, 5 February 2002, http:www.zmag.org/content/TerrorWar/walkom_war.cfm, p. 1.

27. Ibid., p. 2. 
Not since novelist Ian Fleming invented SPECTRE, the shadowy force of evil dedicated to eliminating 007 agent James Bond, has the world's imagination been served in quite the same way. Is there a rebellion in the Philippines? Al Qaeda is responsible. A plot in Malaysia? Al-Qaeda again. Like Fleming's SPECTRE, al Qaeda has access to unlimited funds. Its leaders, like the villains of Bond movies, live in vast underground complexes staffed by fanatical minions. ... In George Orwell's Nineteen Eighty Four, the enemy of the state is personified in Emmanuel Goldstein. Goldstein is the Osama bin Laden figure of the novel, an elusive figure who is never seen, never captured but believed by all patriotic citizens of Oceania ... to be an evil genius bent on their destruction. Since Goldstein is never captured, Oceania's battle against him must never cease. Sometimes it wages war on one country said to be aiding the nefarious Goldstein, sometimes another. The battleground may change but the war never ends. It cannot. The government's very existence depends upon it. ${ }^{28}$

The USA is now preparing for a new phase of this war, the war against the 'Axis of Evil'.

\section{Perpetuating the hatred}

We can now see why America was so uninterested in the Taliban's offer to hand over bin Laden for trial or Huq's proposal for overthrowing the Taliban. Such solutions did not support the dramatic development of the plot required to support the role Bush wanted to play. What was required was a massive attack on Afghanistan displaying the enormous power of the US military without ending the story. As in the build up to the Gulf War, this attack was preceded by a portrayal of the enemy as an almost invincible foe. A poor bunch of tired Taliban were represented as superhumanly tough soldiers, Afghans who had only been defeated twice in their long history, once by Alexander the Great, the second time by Tamerlane in the 14th century. These were the people who had defeated the British in the 19th century and the Soviet Union in the 20th century. This, along with their status as supporters of evil, justified throwing everything in the US arsenal at Afghanistan, bombing the country with everything short of nuclear weapons. Bush was to be the successor of Alexander the Great and Tamerlane.

The US had soon killed more innocent civilians than had been killed in the attack on the World Trade Center and guaranteed that many more people will be blown up in the future. ${ }^{29}$ Widely used cluster bombs scatter as many as 200 bomblets over a wide area. Routinely, these do not explode on impact and remain to exact a death toll for years. Villages were razed. Human Rights Watch reported

28. Ibid.

29. The number of deaths was carefully documented by Professor Marc W. Herold. See 'A Dossier on Civilian Victims of United States' Aerial Bombing of Afghanistan: A Comprehensive Accounting', December 2001, http://www.zmag.org/herold.htm. 3767 civilians were documented as having been killed in the first eight and a half weeks. 
that the village of Chowkar Karez, $40 \mathrm{~km}$ north of Kandhahar, was bombed at night by US planes. 'Many of the people in the village ... ran out of their homes, afraid that the bombs would fall on their homes. All witnesses stated that aircraft then returned to the area and began firing from guns. ${ }^{30}$ When asked to respond to this report, a Pentagon spokesperson said on 2 November 2001, 'The people there are dead because we wanted them dead. ${ }^{31}$ There was no evidence of anything of military value in Chowkar Karez. However, people killed directly by bombing were only the beginning. The air strikes quickly turned the cities into ghost towns and by late October over a million people had fled their homes. Most fled to the country where there is little food or shelter. The country had been suffering from a drought, probably caused by global warming, and it was late autumn and winter was approaching. Hundreds of thousands were starving with the means to deliver food having been destroyed by the bombing. ${ }^{32}$ A spokesperson for the UN High Commissioner for Refugees warned that 'We are facing a humanitarian crisis of epic proportions in Afghanistan with 7.5 million short of food and at risk of starvation.' 33 The UN Food and Agricultural Organization pointed out that bombing had disrupted planting that provides $80 \%$ of the country's grain supplies. The possibility on which the US was basing its war plans was that the war 'might lead to the death of several million innocent civilians'. ${ }^{34}$

It appears that a great many Taliban soldiers were also killed, although there has been no tally. Those who survived have been denied standards of treatment set by the Geneva Conventions. Troops at Konduz surrendered on the understanding that they would be treated fairly. General Rashid Dostrum, known internationally for his brutality, had promised to turn them over the UN and international courts. ${ }^{35}$ After surrender, the soldiers were tied to each other and taken to the Northern Alliance fort at Mazar-I Sharif. It soon became evident to the prisoners that they had been duped. One of the prisoners was the American Muslim, John Walker. He told Newsweek's Colin Soloway, 'Some of the Mujahadeen (Taliban) were scared. They thought we were all going to be killed. ${ }^{36}$ The prisoners rioted, killing CIA interrogator Dave Spann after his CIA colleague had shot dead three prisoners in cold blood. In the next four days, 600 prisoners were slaughtered by Northern Alliance troops, US special forces and British troops with the aid of US Air Force bombers. Sixty prisoners survived all this in the fort's sub-cellar. When they were discovered, Newsweek reported, 'Alliance soldiers poured diesel fuel into the basement and lit it, on the assumption that any remaining Taliban would be killed by the fire and the

30. Quoted by Sonia Kolhatkar, 'By Any Standard, This is a War Against Afghans', p. 1, Znet, http://www.zmag.org.

31. Ibid.

32. Chomsky, 'The War in Afghanistan', p. 4.

33. Ibid., p. 2.

34. Ibid.

35. See Patrick Cockburn, 'Dostrum: The Treacherous General', The Independent, 1 December 2001, http://www.zmag.org.

36. Quoted by Danny Schechter, "The "Turbanators" and the Terrorists: War Crimes and Media Omissions', Mediachannel.org, 7 December 2001, p. 5, http://www.mediachannel.org/views. 
fumes'. ${ }^{37}$ When this strategy failed, the cellar was flooded with freezing water. When it was all over, dozens of the dead prisoners in the fort were found to have had their hands bound and there were reports of men with bullet holes through their heads.

Other prisoners have been blindfolded, chained and deported to Camp X-Ray in Guantanamo Bay, Cuba in conditions, according to Charles Glass, that compare unfavourably to the conditions he endured as a prisoner of the Hezbollah in Lebenon for two months. ${ }^{38}$

Such behaviour is producing the desired result. The brutal treatment of the Taliban justified the view that they were sub-human (just as the brutal treatment of Jews by the Nazis convinced most Germans that they were sub-human and the brutal treatment of Palestinians convinced many Israelis that they were subhuman). Brutality has been accepted as part of the War against Terror. Bush has retained his popularity despite increasing levels of unemployment and a scandal over the collapse of the energy company, Enron, in which Republicans were deeply involved. Bush's 'Economic Stimulus Bill' designed to give back US\$140 billion in taxes to corporations, was passed by the House of Representatives. He has committed the government to an immediate colossal increase in military spending - a further gift to corporations. Lockheed-Martin alone received a contract worth US $\$ 200$ billion. Bush can now carry out his agenda of militarising space, effecting a massive transfer of wealth to the wealthy within USA and undermining or getting rid of international institutions and third world governments standing in the way of, or merely not facilitating, complete US domination of the world's resources.

More importantly, Bush the Younger is following in Bush the Elder's footsteps in creating the conditions for further attacks on the United States. US behaviour towards Afghanistan is likely to produce more recruits for terrorist organisation s like al-Qaeda. As Stephen Shalom pointed out:

The decision to become a terrorist is not one that people make lightly. To kill civilians - not to mention oneself - takes a degree of fanaticism not easily achieved except under extreme circumstances, where deep anger and frustration become unleashed. It takes years of suffering at the hands of an arrogant oppressor, or watching loved ones brutalized. This is why terrorism rarely leads to peace, but instead to more terrorism, in an escalating cycle of violence. Terror by one side does not justify counter-terrorism, but one usually provokes the other, nonetheless.

The US war in Afghanistan will probably add to the number of terrorists who hate the United States. Every innocent civilian who dies in that war has relatives, and these relatives are unlikely to draw as the lessons of these deaths that violence is wrong or that killing civilians is unacceptable. On the contrary, this is the sort of situation that can drive

37. Quoted in Chomsky, 'The War in Afghanistan', p. 8.

38. Charles Glass, 'I Know What Camp X-Ray Feels Like', The New Statesman, 29 January 2002. http://www.zmag.org. 
someone to adopt nihilistic violence or see civilians as legitimate targets. This will especially be the case when the country responsible for the dead relatives behaves in an arrogant manner. ${ }^{39}$

It is not only those immediately affected by the war who will be pushed in this direction. The sheer arrogance of the United States in ignoring international law and international institutions such as the United Nations, combined with its previous history and present policies are having an impact throughout the Islamic world. The US by its actions is telling the world that the lives of people who are not Americans are of little significance. Only affluent US citizens really matter. It is setting itself above the community of nations. The Washington Post reports that Bush has given secret instructions to the CIA to launch covert operations against 80 countries ${ }^{40}$ According to the Vice President, Dick Cheney, the new war may last 50 years or more. ${ }^{41}$ Again, as Shalom noted:

[T] he US reserved for itself not just the right to unilaterally judge the evidence against bin Laden, unilaterally deliver an ultimatum to the Taliban, unilaterally assess the response, and unilaterally go to war. Washington went further, delivering a note to the Security Council indicating that US self-defense measures might require it to attack other countries of its choosing - essentially announcing an open-ended right to sit as judge and executioner of the entire world. This was arrogance with a vengeance - and it was hardly likely to reduce the intense anger at the United States among so many Arabs and Muslims. ${ }^{42}$

The terrorists who sacrificed their lives by highjacking planes and crashing them into the symbols of American power manifest the depth of hatred for the United States, a hatred generated by the actions of George Bush Sr. The actions of George Bush Jr will further intensify this hatred and lead to further attacks on US citizens. The new myth of American nationhood, of America as victim, is being made by Bush into a self-fulfilling prophecy. This will in turn further entrench this myth and the power of the extreme right in US politics.

\section{The anatomy of hatred}

How is it possible for 19 Arabs to hijack planes and kill themselves in order to kill thousands of innocent civilians? How is it possible for Americans in response to approve a war in Afghanistan that is likely to result overall in deaths of more than a million innocent people and leave the rest of the population utterly impoverished? What is hatred and how does it move people to action? In answering these questions it is not so important to understand the people who

39. Stephen R. Shalom, 'Confronting Terrorism and War', New Politics, No. 32, Winter 2002, p. 8, http://www.zmag.org/shalom-confront.htm.

40. Reported by Peter Hartcher, 'Indonesia Joins Axis of Not-so-Evil Nations', Financial Review (Australia), 8 February 2002, p. 23.

41. See John Pilger, The Mirror, 29 January 2002. http://www.zmag.org.

42. Shalom, 'Confronting Terrorism and War', p. 8. 
make the major decisions. It is not certain that bin Laden and Bush are moved by hatred at all. They might be, but then again they might not. Howard Hart, a retired CIA officer who worked for 20 years in the Middle East and South Asia, suggests that "bin Laden is not driven by hatred but is pursuing an ambitious grand strategy. His ultimate goal ... is "a reborn, combative and vigorous Islam" in control of governments throughout the Arabic world." ${ }^{43}$ Bush might be coldly calculating what is required to extend his power, his family wealth and the power and wealth of USA. Psychopaths are unusual and it is difficult to judge individual cases. What is more important is to understand large numbers of people coming to share in hatred and choosing to act in concert accordingly.

Hatred is an emotion directed against those who threaten one's very being as a person. ${ }^{44}$ Personhood involves not only a precarious biological existence but also a precarious sense of self-hood constituted through relations of reciprocal recognition. Hatred is associated with asymmetrical relations of recognition and power. There can be hatred on both sides of such asymmetric relations, but they are of different kinds. Hatred is most easily understood as the emotion of defectively recognised, less powerful people. With variations, this form of hatred is the emotion engendered in people experiencing powerlessness at what they believe to be injustices that threaten their personal identity, usually directed towards those who are being unjust to them. Actions to which people are moved by such hatred will involve efforts to turn the tables, to subject the overlords to the conditions the wretched have been forced to endure. The notion of injustice is central to understanding hatred. Injustice is the failure in people's beliefs and actions to properly recognise other people, what they are, what they have been through, what is their situation and what they have striven for and achieved, what are their potentialities and what are their aspirations. This can be associated with bloody-mindedness, contempt of or just indifference to the other. The ultimate injustice to people is treating them as mere objects, as when Nazis treated Jews as so much material to be disposed of or to be recycled as gold (from gold teeth) or lampshades. The hatred of people who are bullied, reduced to mere instruments or sub-human animals and robbed or exploited, and who are powerless to effect change within this situation, commonly erupt in violent action to obliterate everything and everyone associated with the situation that has denies them justice.

Little imagination is required from anyone who knows the history of the rise of Israel and dispossession of the Palestinians, the subsequent misrepresentations of what had happened, the humiliation and brutality to which Palestinians have been subjected, including mass murder, terrorisation, impoverishment, torture and daily humiliation, and their almost complete powerlessness to right this ongoing injustice or to even have it recognised, to understand why Palestinians in Israel feel hatred for Jewish Israelis and for the Americans who have supported them. While this might not lead people to condone suicide bombings, it should facilitate

43. Thomas Powers, 'The Trouble with the CIA', The New York Review of Books, Vol. 49, No. 1, 2002, p. 29.

44. On the theory of emotions of which this is a development, see Hans Jonas, The Phenomenon of Life (Chicago: The University of Chicago Press, 1966), p. 105. 
an understanding of such extreme behaviour. It is less easy to understand other Arabs feeling the same hatred and taking equally extreme action. It requires more imagination, but it is possible to see how Arabs condemned to a life without hope by corrupt rulers addicted to Western luxuries maintained in power by the US who are taking their countries' oil might identify themselves with all oppressed Arabs and hate America as the ultimate source of their oppression and powerlessness. In such circumstances, Palestinians and Iraqi children would symbolise their own less straightforward situations. A movement such as al-Qaeda that appeared to recognise their situation and their significance and offered them identities as heroes who, by striking back at the people responsible for their humiliation, could help revive the social order which made past Islamic civilisation great, would attract such people, even though the movement might ultimately require them to sacrifice their lives.

The hatred by those with power of those who they are dominating, dehumanising and exploiting is more complex. While the oppressed are striving for proper recognition, the powerful are striving to maintain their identities by looking down upon the people they dominate and exploit. Ideally, they will have succeeded in reducing the powerless to predictable things that can be ignored as people for all practical purposes. Such identities, being dependent upon those whom they have defined as inferior-whose recognition is therefore defined as of no significance, is by its very nature fragile. The greater the delusion involved in upholding this sense of superiority, the more any action on the part of the dominated which challenges this state of affairs can undermine their oppressors sense of who they are. It is this power of the oppressed that turns indifference into hatred. When the wretched whom they are bullying and exploiting demonstrate virtues such as courage, intelligence, compassion of which they are incapable, the brittle nature of their identities is exposed. Some means must be found to deny reality, to construe virtues as vices or as proof that the wretched are not really human. Courage in particular seems to worry such people, as is apparent in the way courageous behaviour by Arabs is denigrated as cowardly or dismissed as evidence of a sub-human fanaticism. Capacity for heroism is redefined as a vice, contrasted unfavourably with the comfortable bourgeoisie. The people most prone to such hatred will be those whose position of domination is based on their inherited wealth, standing and power and who are manifestly inferior in important respects to the people they are structurally defined as superior to.

The most intense hatred is the product of the interaction between these two different forms of hatred. Frequently, those who are bullied and denied due recognition feel hatred, but instead of directing this against those who have humiliated and oppressed them, they identify with their oppressors and direct their hatred against those who are more wretched. Moved by this hatred, they gain a sense of their own significance by bullying, debasing or looking down on such unfortunates while taking this as evidence of their own superiority. Such people are then doubly threatened by resistance of the wretched because this both highlights their own invidious position in relation to the powerful whom they have subordinated themselves to and identified with, and reveals the illusions of their supposed superiority over the wretched in relation to whom they have defined themselves as significant. This is a threat to their entire world and the 
place they have within it. Racist poor white southerners in USA used to lording it over blacks, and the lumpenproletarian Nazis of Germany who attacked the Jews, were prototypical cases. Such people, full of hatred, become major supporters of hierarchical structures of hatred and oppression.

In the light of this analysis it is not difficult to see how Bush's politics of hatred functions. The USA is a country brutalised by market-fundamentalist economic policies supported and implemented by both major political parties over the last 25 years. This has produced massive inequalities of income, wealth and power and a strong sense of impotence to affect the policies producing this. It has left vast numbers of people permanently devalued, economically insecure with little hope for a better life. At the same time, the USA with $4 \%$ of the world's population is consuming $40 \%$ of the world's resources, and bullying much of the rest of the world to maintain access to these resources. With the help of bin Laden and, more fundamentally, George Bush Snr, George Bush Jr has aligned the almost inevitable feelings of hatred this has generated against people outside the USA, whose resources (and cheap labour) are being exploited. American employees, reduced to mere labour power competing with a global reserve of unemployed and faced with clear evidence of the corruption of their democratic institutions, can now exalt in being Americans. They can identify with its military might and satisfy their feelings of hatred in television pictures of an impoverished nation being obliterated and its imprisoned soldiers being slaughtered or brutally humiliated. With this structure of hatred in place, Bush can proceed to further distribute wealth to the wealthy, to corrupt democratic procedures and institutions and to pour money into the military, thereby further undermining the economic conditions of most people and so intensifying their feelings of hatred.

\section{Beyond hatred: the struggle for recognition and justice}

Almost everyone, at least in print, assumes that the attack on the twin towers was wrong and counterproductive, although there has been some suggestion that the outcome of the war is precisely what bin Laben hoped for. Mas'ood Cajee suggested in 'bin Laden's Hiroshima', bin Laden

knows that Washington, in a fit of bloodlust and blind rage, will not surrender or withdraw. Instead the US government will intensify the problems of the Muslim world, because it is presently incapable of solving them. He calculated that the richest country in the world would take the bait, and bomb the planet's poorest country. He knows his support grows in the Muslim and Third World with every 2000-pound American bomb dropped on residential neighborhoods of Kabul or Kandahar. ${ }^{45}$

Bin Laden has further exposed the ruthlessness and hypocrisy of Americans and the complicity of Arab leaders in US domination of the Arab world, at least to

45. Mas'ood Cajee, 'bin Laden's Hiroshima', Fellowship Magazine, November/December 2001, p. 1, http://www.forusa.org/Fellowship. 
people in the Islamic world. Arguably, by strengthening Bush and his brutal economic and social policies this will pave the way for the future social and cultural disintegration of USA.

There is, however, a very real possibility that in the meantime increasing the power of men such as Bush and further entrenching their policies will set the world on a path towards an American based, extremely brutal global police state in which Arabs, their population thinned out by wars, will be reduced to the condition of American Indians. As Walter Laqueur has argued, terrorism has been a singularly unsuccessful strategy, at least when used by the weak (he ignored it as a strategy of powerful states, where it appears to have been much more successful). ${ }^{46}$ It is fundamentally flawed because it reproduces the stratagems of the oppressors.

In fact, what $I$ have been suggesting here is that the response of al-Qaeda is precisely what people like Bush want as part of their strategy to create a global police state in which subordinate states are disciplined by the free flow of capital, political assassinations, thugs like those supported by the USA in Afghanistan and a space-based, computer-controlled, nuclear-weapons system against which every country is powerless. ${ }^{47}$ The people who died in the Word Trade Center and the people who are likely to die in further terrorist attacks on the USA in reaction to US actions, are effectively sacrifices made by the two Bush administrations to generate the structures of hatred required by them to realise their purposes. The problem is, how to oppose the terrorism of the US government.

Those who oppose Bush's war on Afghanistan and, more broadly, his War against Terror, have been struggling to expose the simplistic thinking that underlies it. There is no simplistic alternative. Rather, there is a slow struggle to reveal the particulars that are overlooked in hype of grand gestures and victory celebrations and to put the issues in broader perspective. Particulars include preeminently the suffering and death of innocent Afghans who have been killed by bombs or starved or frozen to death as refugees. The broader perspectives required are the longer history of Afghanistan, of the Arabic and Islamic worlds, of European subjugation of the world and of US involvement in world affairs. This involves showing the culpability of the US government in what happened and highlighting the hypocrisy and likely evil consequences of its present actions.

One of the most effective means of achieving this is the Kantian approach of Chomsky, looking at every US action on the basis of what would happen if the principles on which it has been acting were universalised. Responding immediately to Bush's plan of action enunciated soon after 11 September, Chomsky asked:

What was the right way for Britain to deal with IRA bombs in London? One choice would have been to send the RAF to bomb the source of their finances, places like Boston. Putting aside feasibility, that would have been criminal idiocy. Another possibility was to consider realistically the background concerns and grievances, and to try to

46. See Walter Laqueur, Terrorism (London: Weidenfeld and Nicolson, 1977).

47. See Chomsky, 'September 11th and its Aftermath', p. 8 on this military agenda. 
remedy them, while at the same time following the rule of law to punish criminals. ${ }^{48}$

This Kantian approach, demonstrating the insanity of universalising the US government's principles of action, has been thought through consistently by Chomsky and elaborated in much more detail to show that there was an alternative path, and that this should and could have been taken. Objections to his arguments were considered in an interview with Stephen R. Shalom, ${ }^{49}$ (who later developed a more complex argument against the war, essentially supporting Chomsky's conclusions and countering all objections that might be raised against them).$^{50}$

However, this is not the path that was taken. Why? What such analyses leave out are the emotions that move people. To begin with, there are the emotions of those who are hostile to America. As David Edward wrote,

$[\mathrm{H}]$ istory is sure to swallow the vapid cries of 'Victory!' in its vast and bloody maw. The folly of the course on which we are set is hidden from the public by years of suppression and omission of embarrassing truth. First, there is the sheer scale and depth of hatred ranged against the United States and its allies..$^{51}$

This is a real problem, because as I have tried to show, these emotions and their inevitable consequences will be used by Bush to further justify what he is doing. More important are the emotions of the Americans and their supporters who somehow found killing vast numbers of Afghans deeply satisfying, and who are exhilarated by the prospect of a high-tech War against Terrorism to combat those who hate the USA. What has to be appreciated is the attraction of defining oneself through hatred of the other, particularly in a world that provides no support for and undermines any other basis by which people might define themselves. To overcome hatred, it is necessary for people to find an alternative mode of identity formation.

This does not mean that the Kantian approach should be rejected, but it is important to appreciate that there is more involved than finding universalisable principles. As Kant argued, such universalisability is equivalent to treating people always as ends in themselves, and never as mere means. Developing this aspect of Kant's philosophy, Hegel developed an ethics based on the notion of recognition, and through this, attempted to overcome the opposition between self-interest and the 'moral ought' ${ }^{52}$ It is through the quest for recognition (acknowledgement, respect, esteem, admiration, love), the condition for attaining self-hood, that people tend to strive for and to create relations of mutual

48. Noam Chomsky, 'Composite Interview \#3, Sept 22', Znet, http://www.zmag.org.

49. 'Stephen R. Shalom Interviews Noam Chomsky', Znet, http://www.zmag.org/shalom0122. htm.

50. Stephen R. Shalom, 'Confronting Terrorism and War', New Politics, No. 32, Winter 2002, http://www.zmag.org/shalom-confront.htm.

51. David Edwards, 'History Will Not End Here: Chomsky's 9-11', 23 January 2002, Znet, http:// www.zmag.org, p. 1

52. On this, see Robert R. Williams, Hegel's Ethics of Recognition (Berkeley: University of California Press, 1997). 
recognition, relations based on a commitment to justice, and to create and sustain social orders in which the significance of all people is recognised. ${ }^{53}$ Those committed to justice in this sense are defining themselves and participating in the creation and advancement of a community of all those throughout history who have been and will be committed to justice. This in essence is civilisation. Other bases for self-definition ultimately undermine themselves. Hatred as a basis for self-definition, for instance, is contingent on existing power relations and, as I have suggested (following Hegel), undermines the basis for reciprocal recognition that is the condition for achieving a true self. This is why in the long run, social forms based on hatred are unstable and tend to lose out to social forms based on the commitment to justice. The advance of civilisation is the advance in proper recognition accorded to people. The history of civilisation has been a continual struggle, frequently unsuccessful, against barbaric forms of identity formation that deny such recognition. What we see with Bush, the war against Afghanistan and the jingoistic sabre rattling of the US and the myth of the USA as victim entitled to terrorise the world, is a new outbreak of barbarism.

There is another dimension recognised by Hegel: that the most important reciprocal recognition is that which is institutionalised. Chomsky (and Shalom) recognise this when they uphold the importance of the World Court and the United Nations and the need to operate through them. For most people, the most important institutions are those associated with everyday life. Barbarism flourishes when the institutions through which people are able to achieve a stable identity in their everyday life begin to fall apart. This is what happened in Weimar Germany, facilitating the rise of Nazism. In the era of the social democratic consensus there was a far greater commitment by the general population to global justice and the institutions required to uphold it. The dissolution of this consensus associated with the globalisation of the market and the rise of market fundamentalism, undermining people's economic security and the democratic political institutions that formed the basis of people's identities, has provided the conditions for xenophobic hatred. As Chomsky noted elsewhere, 'the threats to survival are currently being enhanced by dedicated efforts to weaken the institutional structures that have been developed to mitigate the harsh consequences of market fundamentalism and, even more important, to undermine the culture of sympathy and solidarity that sustains these institutions '. ${ }^{4}$ The struggle against barbarism will require a concerted effort to create institution s embodying a commitment to justice to replace those destroyed by the market fundamentalists.

This struggle will require the creation of a perspective through which the interconnections between all the issues involved can be appreciated. Bush and those he represents have created a mutually reinforcing system of hatred in which hatred has been channelled to reproduce the conditions for generating and

53. See Axel Honneth, The Struggle for Recognition: The Moral Grammar of Social Conflicts, trans. Joel Anderson (Cambridge, MA: MIT Press, 1996).

54. Noam Chomsky, 'September 11th and Its Aftermath: Where is the World Heading?', Public Lecture at the Music Academy, Chennai (Madras), India: 10 November 2001, p. 9, Frontline: India's National Magazine, Vol. 19, No. 3, 2002, http://www.hinduonnet.com/fline. 
intensifying this hatred, and reinforced this system of hatred with a new myth of the American nation as victim and saviour. A myth is a story and to oppose such stories an alternative story is required, a story that is not a myth but is underpinned by a commitment to truth. This story should not only provide a perspective on the world, it should also offer a vision of the future and orient people to participate in realising this future. ${ }^{55}$ Such a story needs to reveal the ploys and delusions of barbarian myths and reveal all facets of the problems that need to be addressed to begin to realise a better future. It should simultaneously be committed to a full and true recognition of people in the past, the present and the future, and to embodying this in the social reality of the future. That is, it should be a story committed to doing justice to everyone and to orienting people to realise justice in their practices. Of course this is an immensely difficult task that will require an enormous amount of work. The present paper is offered as a contribution to the development of such a story.

55. On the nature of stories, their relation to action, to visions of the future and to orienting people to strive for such visions of the future, see David Carr, Time, Narrative, and History (Bloomington: Indiana University Press, 1986). See especially p. 151, n. 31. 
Copyright of Democracy \& Nature: The International Journal of Inclusive Democracy is the property of Carfax Publishing Company and its content may not be copied or emailed to multiple sites or posted to a listserv without the copyright holder's express written permission. However, users may print, download, or email articles for individual use. 